\title{
The old and the new concepts of histochemistry
}

\author{
Giuseppe Musumeci \\ Correspondence: g.musumeci@unict.it \\ CrossMark \\ $\leftarrow$ Click for updates
}

Department of Biomedical and Biotechnological Sciences, Human Anatomy and Histology Section, School of Medicine, University of Catania, Via S. Sofia 87, 95123 Catania, Italy.

\begin{abstract}
With great pleasure, I present this second editorial for the second volume of the Journal of Histology and Histopathology. Special thanks go to Senior Editor Dr. Gjumrakch Aliev and our current editorial team (Sherif M Karam, Xueyong Zhu, Khin Thway, Han-Seung yoon, Paul Evans, George Perry, Khush Mittal, Paola Castrogiovanni, Lingyan Wang, Karin Pichler, Stefano Fratoni and Niki J. Agnantis) and the publishing group (Herbert Publications) that, day after day, thanks to their valuable contribution, make possible the growth of this journal. I can say with great satisfaction that the number of submissions continues to increase; this will allow us to achieve some important goals that will contribute to the growth of our journal. For this reason I invite our editorial team to continue to be more scrupulous in their review process to maintain the high standards and the roles of the journal and to assure rapid publication. I sincerely thank them in advance for their precious time. Another important goal is for the journal to be indexed by other important bibliographic database, such as PubMed/Medline, Scopus, EMBASE, ISI Web of Science, Index Copernicus and so on. The purpose of this editorial is to outline a brief overview to explain my view on histochemistry.
\end{abstract}

Keywords: Histochemistry, cytochemistry, autoradiographic, histology

\section{Editorial}

\section{Histochemistry}

Histochemistry has an interesting history, extending back to ancient times when researchers had a desire to understand the functions of the human body and the roles that various "humors" or chemicals have in those processes [1]. Histochemistry is the study of the distribution of chemical compounds within and between biological cells using histological techniques such as histology stains (Table 1), through various colorants (Table 2) and observed under light (optical) and electron microscopy [2]. This science provides information on the content and the nature of the chemicals in biological tissues examined, rather than on morphological appearance of the preparation. To highlight a particular functional group or a particular ion present in various tissues and cells, scientists perform one or more chemical reactions, stoichiometrically exact and specific. The colored precipitates obtained will be analyzed by the optical microscope, or in the case of fluorophores, fluorescence microscopy.

Histochemistry took its first steps in the early 1950s but it was between the 1950s and the 1960s that discoveries in histochemistry, cytochemistry and autoradiography prospered.
Enzyme histochemistry gained popularity with the development of new techniques and applications to localize enzymatic activities in cells and tissues, evolving into a major discipline in the life sciences and pathology [3]. The transmission electron microscope was introduced in the 1960s leading to significant discoveries in cell ultrastructure and functions of cell organelles, such as lysosomes and peroxisomes [4]. Autoradiography allows us to study dynamic aspects of cell biology, by both the light and electron microscope [5]. Histochemistry takes its origin from medical sciences such as biochemistry and histochemistry that have become so advanced that they have giving rise to specialist sub-disciplines. Those subjects are not usually debated in school or college-level courses, but they may address students to further scientific subjects at more advanced levels [6]. The histochemistry includes cytochemistry, immunohistochemistry and immunocytochemistry [7]. Cytochemistry is the study of the actions of chemical compounds within living cells. Immunohistochemistry allows us to detect antigens using antibodies binding to specific targets in sections of biological tissue, in which each cell is surrounded by the tissue structures and other cells normally found in the intact tissue. Immunocytochemistry uses antibodies to target specific 
Table 1. Colorants commonly used.

\begin{tabular}{lll}
\hline Name & Type & Affinity \\
\hline Eosin & Basic & Stain the nucleus light pink \\
Hematoxylin & Acid & Stain the cytoplasm blue-violet \\
Toluidine blue & Amphoteric & $\begin{array}{l}\text { Stain the nucleus blue-violet } \\
\text { Stain nucleic acids blue-violet }\end{array}$ \\
& & Stain the cytoplasm blue-violet \\
& & Stain some polysaccharides red \\
Fuchsin acid & Acid & Stain erythrocytes orange \\
Methyl violet & Acid & Stain amyloid purple \\
Green light & Basic & Stain collagen fibers green \\
Alcian blue & Basic & $\begin{array}{l}\text { Stain some mucosubstances } \\
\text { (glycosaminoglycans) blue }\end{array}$ \\
Congo red & Amphoteric & $\begin{array}{l}\text { Stain nuclei blue } \\
\text { Stain amyloid red }\end{array}$ \\
& & Stain connective red \\
\hline
\end{tabular}

Table 2. Some widely used histochemical staining.

Hematoxylin and eosin
Ziehl-Neelsen
PAS reaction
Prussian reaction
Feulgen reaction
Hillarp reaction
Mallory's trichrome
Masson's trichrome
van Gieson's trichrome
Gomori trichrome
Goldner trichrome
Trichrome Heidenhain (Mallory-Azan)
Nissl method
Azan
Orcein
Ignesti
Iron Hematoxylin (hematoxylin Heidenhain)
Alcian Blue
Giemsa \& Wright
Toluidine blue
Methyl green-pyronin
Sudan black/Osmium

peptides or protein antigens in cells that could have been grown within a culture, deposited from suspension, or taken from a smear. Indeed immunocytochemistry is different from immunohistochemistry because the tissues studied have their surrounding extracellular matrix removed [7]. The scope of histochemistry has expanded over the years in pathological diagnosis and research including new techniques involving specific antibodies, imaging, quantification, and in situ hybridization. The quantification of stained or immunolocalized images of specific colored reaction products is made by computerized image analysis systems (such as ImagePro ${ }^{\circledR}$ or analySIS ${ }^{\circledast}$ ) and similar software packages [8] that measure and compare changes in the intensity of staining reactions. Several histochemical methodologies have risen and fallen during the last couple of decades, including the use of colloidal gold labeling at the ultrastructural level [4]. Transmission electron microscopy has been replaced in much histopathology diagnostics by novel light microscopy techniques including the use of specific monoclonal antibodies [6,9]. Light microscopy techniques are indeed experiencing a period of renaissance, with novel techniques using super-resolution microscopes and live cell imaging [10]. Confocal light fluorescence microscopy provided clear images of the morphology of cells. Autoradiographic methods lost their role as a result of safety issues and special requirements of radiation safety officers in dealing with radioactive compounds, especially because alternative methodologies are often available [8]. The recent molecular biological techniques allow us to correlate quantitative data to the microscope images using histochemical, cytochemical and tissue microarrays techniques [11]. We are also seeing the increasing use of histochemical research in this extremely fertile period of cell biology which has led to the establishment of new scientific journals devoted specifically to histochemistry and cytochemistry (Table 3).

Table 3. Some Scientific histochemistry and cytochemistry journals.

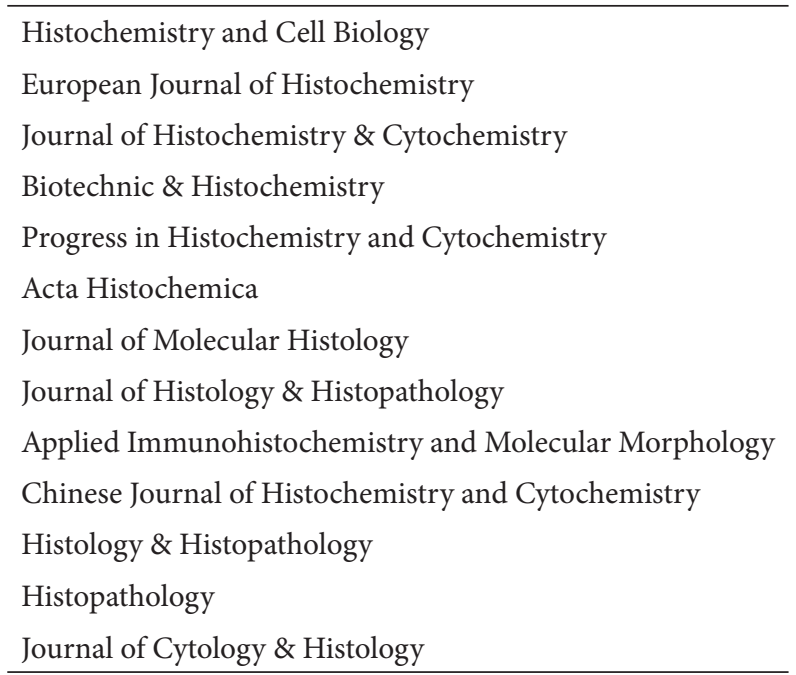

\section{Conclusion}

In its long history, histochemistry had many connections 
with the other life sciences. It is now one of the most objective methods in biology and medicine, used in a variety of clinical differential diagnostic settings. The rapidity, reproducibility, and relatively low costs related to this technique, allow it to maintain its value after nearly 200 years of existence. With this editorial I want to remind us of the evolution of this investigative and diagnostic discipline that began from the efforts of medicinal chemists and then rose to be at the basis of current practice of anatomical pathology, combining histology and biochemistry. In conclusion, I can hypothesize that the use of histochemistry is currently widespread and very important both for scientific research and for clinical diagnostics, without which we would not be able to evaluate some morphological alterations of both cells and tissue.

\section{Competing interests}

The author declare that he has no competing interests.

\section{Acknowledgement}

I thank Professor Gaetano Magro from Department of Medical and Surgical Sciences and Advanced Technologies, G.F. Ingrassia, Azienda Ospedaliero-Universitaria "Policlinico-Vittorio Emanuele", Anatomic Pathology Section, University of Catania, Catania, Italy, for his kind support.

\section{Publication history}

Editor: Lingyan Wang, Oregon Health \& Science University, Portland.

Received: 06-Mar-2015 Final Revised: 01-Apr-2015

Accepted: 14-Apr-2015 Published: 21-Apr-2015

\section{References}

1. Wick MR. Histochemistry as a tool in morphological analysis: a historical review. Ann Diagn Pathol. 2012; 16:71-8. | Article | PubMed

2. Titford M. Progress in the development of microscopical techniques for diagnostic pathology. J Histotechnol. 2009; 32:9-19. | Pdf

3. Coleman R. The impact of histochemistry--a historical perspective. Acta Histochem. 2000; 102:5-14. | Article | PubMed

4. Coleman R. Professor Moshe Wolman: pioneer in histochemistry. Acto Histochem. 2002; 104:117-21. | Article | PubMed

5. Ostrowski A, Nordmeyer D, Boreham A, Holzhausen C, Mundhenk L, Graf C, Meinke MC, Vogt A, Hadam S, Lademann J, Ruhl E, Alexiev U and Gruber AD. Overview about the localization of nanoparticles in tissue and cellular context by different imaging techniques. Beilstein J Nanotechnol. 2015; 6:263-80. | Article | PubMed Abstract | PubMed Full Text

6. Coleman R. The long-term contribution of dyes and stains to histology and histopathology. Acta Histochem. 2006; 108:81-3. I Article I PubMed

7. Musumeci G, Castrogiovanni P, Mazzone V, Szychlinska MA, Castorina $\mathrm{S}$ and Loreto $\mathrm{C}$. Histochemistry as a unique approach for investigating normal and osteoarthritic cartilage. Eur J Histochem. 2014; 58:2371. I Article | PubMed Abstract | PubMed Full Text

8. Coleman R. Acta Histochemica celebrates 60 years of publication (19542014). Acta Histochem. 2014; 116:1-4. | Article | PubMed

9. Musumeci G. Past, present and future: overview on histology and histopathology. J Histol Histopathol. 2014; 1:5. I Article

10. Coleman R. Eponyms in histology and histochemistry: do they still serve a purpose, or should they be abandoned in favor of standard noneponymous terminology? Acta Histochem. 2006; 108:241-2. | Article | PubMed

11. Coleman R. The Kyoto Protocol: beyond the limit of histochemistry. Acto Histochem. 2013; 115:1-2. | Article | PubMed
Citation:

Musumeci G. The old and the new concepts of histochemistry. J Histol Histopathol. 2015; 2:10. http://dx.doi.org/10.7243/2055-091X-2-10 